\title{
CLASSIFICATION AND FEATURES OF SEARCH AUTONOMOUS UNDERWATER VEHICLES CONTROL
}

\author{
КЛАСИФІКАЦІ ТА ОСОБЛИВОСТІ КЕРУВАННЯ ГРУПОЮ \\ ПОШУКОВИХ АВТОНОМНИХ НЕНАСЕЛЕНИХ ПІДВОДНИХ АПАРАТІВ
}

\author{
Leo T. Aloba \\ alobat@gmail.com \\ ORCID: 0000-0002-0509-8129 \\ Л. Т. Алоба, \\ викладач
}

\author{
Admiral Makarov National University of Shipbuilding, Mykolaiv \\ Начіональний університет кораблебудування імені адмірала Макарова, м. Миколаӥв
}

\begin{abstract}
Swarm Intelligence (SI), widely used in the field of swarm robotics (swarm robotics) - the collective behavior of group decentralized, self-organized agents - are superior capabilities of agents' swarm compared to its individual agents. It is studied and applied for a number of different tasks, where a group of autonomous underwater vehicles (AUVs) is used to solve problems with distributed approach. Recently, the need for the group application of intelligent AUVs has attracted considerable attention due to their low cost of serial production, lower costs for the use and maintenance of AUV groups, extended methods in a wider application range, fault tolerance, scalability, flexibility, efficiency enhancement of tasks execution and others. They are used for the intellectual mission tasks execution in the field of a number of important activities, such as pipeline inspections in the gas and oil industries, military implementation, restoration of sunken objects, underwater mine countermeasures and others. The types of AUV group applications provide effective and reliable results for group missions. The classification of AUVs group application methods used for underwater systems control, robotics research and the World Oceans development, which covers the AUVs plane rectilinear and curvilinear motion, as well as their group spatial motion, is proposed. The classification of underwater tasks and methods for solving them, using the AUV group has been developed. The basic methods of distributed group control without the exchange of information and with the need to ensure regular exchange of information between the AUV in the group are presented. A lot of applied scientific and technical tasks on the creation of centralized and decentralized control systems for a group of underwater vehicles performing a common mission are formulated. The obtained results can serve as a theoretical basis for the development of highly efficient systems for the AUV group control automation when performing operations in large areas in underwater environments with uncertainties.
\end{abstract}

Key words: swarm intelligence; group control; centralized control; decentralized control.

Анотація. Ройовий інтелект, широко використовуваний у сфері ройової робототехніки, - це колективна поведінка децентралізованих, самоорганізованих агентів групи, що є чудовою можливістю рою агентів порівняно з його окремими агентами. Він вивчався і застосовувався для низки різних завдань, де група автономних ненаселених підводних апаратів (АНПА) використовується для вирішення завдань 3 розподіленим підходом. Останнім часом необхідність групового застосування інтелектуальних АНПА значною мірою постала у зв’язку з низькою вартістю їх серійного виробництва, зниженням витрат на використання та обслуговування груп АНПА, розширеними методами застосування в більшому діапазоні, відмовостійкістію, масштабованістю, гнучкістю, підвищенням ефективності вирішення поставлених задач та іншим. Вони використовуються для інтелектуального виконання завдань місією в сфері низки важливих видів діяльності, таких як інспекції трубопроводів у газовій і нафтовій промисловості, військове використання, відновлення затонулих об'єктів, контрзаходи підводних мін тощо. Типи групових застосувань АНПА дають ефективні та надійні результати виконання спільної місії. Запропоновано класифікацію методів групового застосування АНПА для керування підводними системами і дослідженнями робототехніки та освоєння Світового океану, що охоплює плоский прямолінійний і криволінійний рух АНПА, а також їх груповий просторовий рух. Розроблено класифікацію підводних завдань і методів їх вирішення за допомогою групи АНПА. Наведено основні методи розподіленого групового керування без обміну інформацією та з необхідністю забезпечення регулярного обміну інформацією між АНПА в групі. Сформульовано низку прикладних науково-технічних завдань зі створення систем централізованого та децентралізованого керування групою підводних апаратів, що виконують спільну місію. Отримані результати можуть слугувати теоретичною основою для розробки високоефективних систем автоматизації групового руху підводних апаратів під час виконання робіт на великих акваторіях у невизначених середовищах.

Ключові слова: ройовий інтелект; групове керування; централізоване керування; децентралізоване керування. 


\section{PROBLEM STATEMENT}

Today, the AUV group application is pertinent in the performance of exploratory and environmental maritime missions and is characterized by high efficiency and effectiveness of their implementation. One of the main issues in organizing the AUV group use is the operational control of several AUVs with the aim of their coordinated motion in the aquatic environment to achieve a common underwater mission (UM). In modern foreign literature there is information about the AUV group application, but there is no complete idea of the scientific problem of motion organization and operational control for the AUV group.

In this regard, the applied scientific classification problem of group motion control methods and group application methods of AUVs is relevant, taking into account their technical characteristics, underwater environmental characteristics and the desired underwater objects properties.

The solution to this problem will allow develop theoretical foundations for the synthesis of a new type of marine automatic control systems (ACS) of moving objects - AUV group control systems (GCS).

LATEST RESEARCH AND PUBLICATIONS ANALYSIS

AUVs are a highly efficient form of unmanned marine robotics and are widely used to perform survey and research works over the entire range of depths of the oceans $[1 ; 2]$. A group of AUVs can efficiently perform desired tasks more than what is possible with a single AUV, and with enhanced accuracy.

Swarm robotics (SR) uses the principles of cooperative behavior, observed in nature and often manifested by small insects, birds, etc. [3; 4]. In [5] collective behavior arising from local interactions between robots and the environment is described, and the problem of organizing joint coordinated actions of the group is considered. In [6] the problem of self-organization of autonomous distributed systems in decision-making problems in the face of uncertainty is considered.

A significant number of scientific publications [6; 7] are devoted to questions of AUV group applications. However, today there is no unified system for AUV group application methods classification as a basis for developing appropriate methods for organizing their group motion control. Today, the issues of AUV group application methods general classification and AUV group control methods are not resolved.

THE ARTICLE AIM is to develop the classification of AUV group application methods and of related AUVs group control methods as a theoretical basis highly effective automation systems synthesis of search underwater operations carried out in large water areas.

To achieve this goal, the following tasks are formulated and solved:

- compile the classification of AUV group application methods;
- develop the classification of underwater tasks and the methods for solving them using the AUV team;

- propose the main AUV group application methods.

\section{METHODS, OBJECT AND SUBJECT OF RESEARCH}

Methods of research. The methods used for carrying out the tasks are: linear algebra and analytical geometry methods, general methods of robots group control theory.

Subject of research - a group of search autonomous underwater vehicles performing a common underwater task.

Object of research - classification process and group control features of search autonomous underwater vehicles.

\section{BASIC MATERIAL}

Group AUVs should be able to organize themselves to perform specific tasks in complex operations. However, the AUVs architecture, tasks distribution between them, the control strategy, the control tasks localization and their group coordinated motion organization should be taken into account. The effectiveness of the AUV group application largely depends on the chosen control method. As a result of the typical underwater operation analysis and the methods (technologies) for solving them, using the AUV group [3; 4], and the author offers the AUV group control methods classification.

Depending on the multi-agent system organization method, the AUV group control methods are divided into two main - centralized and decentralized control (fig. 1). It is also expedient to point out the auxiliary control semi-decentralized.

Centralized control consists the presence of a leader-AUV in the group (central-control device (CCD)), which controls all the AUVs in the group directly. All decisions are made by the leader-AUV or the main control computer located onboard and transferred to the executive controllers of the individual group AUVs. This computer collects information about the status of all AUVs as control objects, processes them, and each control object issues its own control command. There are single-leader or hierarchical control.

With centralized single-leader control, there is a leader and many followers in the group. All the AUVs in the group are synchronized with the leader, all AUVs use the same central controller, which operates on the basis of information about all the group AUVs. The leader AUV provides an optimal solution to a joint task, but the failure of the leader AUV leads to the failure in the operation of the entire group.

In centralized hierarchical control, there is a hierarchy tree of control devices [8; 9]. The control center is also directly connected with each group AUV. There are sub-leaders that control the follower-AUVs in their subgroups, which are also controlled by the main AUV leader. The leader-AUVs are equipped with high-precision navigation systems to support the follower-AUVs and each of the follower-AUVs exchange information 


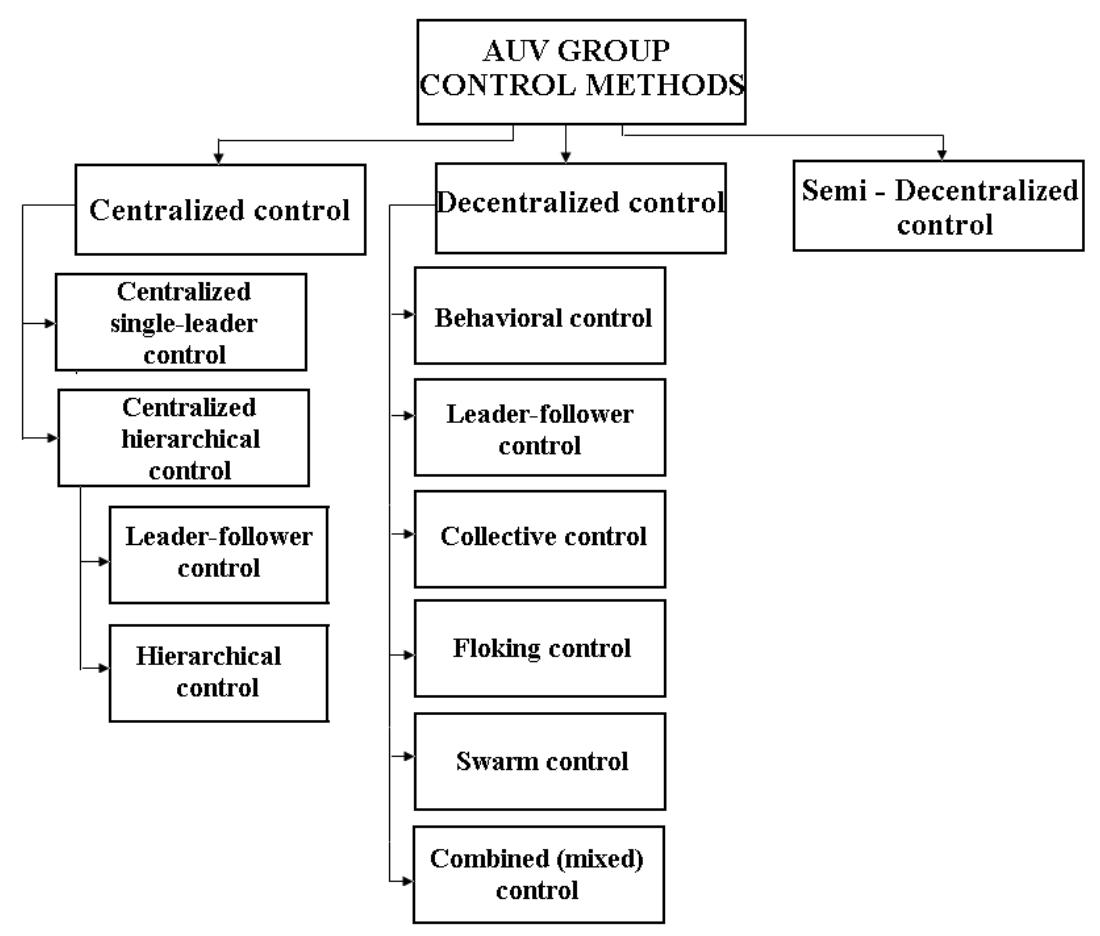

Fig. 1. Classification of AUVs Group Management Methods

with the leader-AUVs. The CCD controls the entire AUV group and, accordingly, plans the actions of individual subgroups. The generated control actions that are prescribed for each AUV are then transferred to the appropriate AUV for execution. For larger systems, hierarchical control is used.

The failure of the main leader-AUV leads to the failure of the entire group. If the leader-AUV in the subgroup fails, a role assignment scheme is used for identifying a new leader-AUV among the sub-group AUVs. This scheme combines such methods as the "leader-follower" approach and the analysis of the fault tree with fuzzy triangles [10].

Decentralized control includes the distribution of control functions between individual independent AUVs of a group, either with (or without) a communication channel. Each AUV is controlled by its own controller, chooses an action (in parallel) based purely on locally observable information an immediate environment and an observation obtained by the closest neighbors of the AUV at a given time.

Decentralized control is effective with an increase in the number of AUVs in the group. The lack of communication between the AUVs limits the achievable performance and if one of the AUVs loses contact with the command center, it is not possible to use it in the group.

There are two different approaches to the coordination and organization of the AUV group - behavior control and leader-follower control [8; 9].

Group behavior control is based on the AUVs intelligent behavior in the group when performing a com- plex UM (search, survey, measurement, etc.). Each AUV group operates independent of the other AUV groups, having the ability to exchange operational data with them.

The advantage of such control is that the group dynamics contains feedback that allows being proactive and automating complex UMs performance process. The disadvantage is that group behavior is unpredictable.

In the leader-follower control approach, AUVs are divided into leaders and followers (as explained earlier).

There is also a combined (mixed) control in accordance with the hierarchical principle, when there are large numbers of groups, and the AUV groups are also divided into smaller groups [11].

Depending on the possibility of coordinating individual decisions, decentralized control strategies are divided into collective, flocking, swarm and combined control strategies [12].

In AUV group collective control method [13], each group AUV receives information from the entire group AUVs and transfers the collected information about the environment and its own state to the communication channel for accessibility to the other entire group AUVs and optimizes the group collective actions. Each AUV independently determines its necessary actions [14]. The choice of actions by the AUV group is carried out only on the basis of the information about the group goal, the current environment situation, the current conditions and the actions of other AUV groups to achieve a common goal; compromises are allowed. Collective control strategies allow a group to remain operational in the event of failure of one or more group AUVs. 
In flocking control, there is no dedicated communication channel for exchanging information between the AUVs. Each AUV independently collects information about the environment and decides on its next actions to perform a group task [12]. All AUVs perform the same algorithm, and their actions are independent and asynchronous from each other. Each AUV can perform more than one operation and can change one for another. The advantage of such control is scalability: with an increase in the number of group AUVs, the control tasks' computational complexity does not increase.

Swarm control is based on the swarm intelligence (RI) idea, as in the natural world (bee colonies, ant colonies, etc.) and controls the combination collective behavior of homogeneous portable and cheap AUVs with good maneuverability and communication, has a short range communication system only with its closest AUVs and does not require any central coordination. Each AUV makes its own decisions regarding current behavior based on environmental data and from the neighboring AUVs, which are issued in the form of local rules. Two scenarios are possible, by the nature of the information exchange.

The advantage of such control is a more optimal solution to the information exchange problem in AUV groups to achieving collective goals $[12 ; 13]$.

1. When the AUV detects a target, it informs the neighboring AUVs, which transmit this information to their neighbors; as a result, the information becomes known to all the AUV groups; subsequently, they change the motion path to the goal.

2. When the AUV detects a target, but cannot transfer its coordinates to other AUVs; he changes its motion path to the goal; the other AUVs, following the rules of their closest neighbors, will follow it, and he will become the leader-AUV.

Below is a list of some SI algorithms, which reflect the approach essence to task solutions [15]: Ant colony optimization (ACO); Bees algorithm - BEECLUST; Particle Swarm Optimization (PSO); Bacterial Foraging Optimization (BFO); Stochastic Diffusion Search; Gravitational search algorithm; Intelligent Water Drops algorithm; Firefly Algorithm (FA).

In semi-decentralized control there is a local connection between the AUVs. This type of group control is carried out from the centralized strategy to decentralized strategies [8] with intermediate actions, and at the same time works for the benefit of the entire AUV group as a whole, where there are elements of both centralized and decentralized control. In this control method, there is a leader-AUV that distributes tasks to the group AUVs and each AUV achieves its goal by making its own decisions.

Advantage: the effectiveness of centralized control and communication requirements is practically achieved. Disadvantage: there are challenges due to delays, packet drops, etc.
Based on the experience study of successful AUV group application by the leading maritime nations of the world in [15], the following underwater tasks classification and methods for solving them using the AUV group is proposed:

- centralized control: 1) front (line) motion; 2) ledge (echelon) motion; 3) wedge motion; 4) radial motion (converging and diverging); 5) motion in a circle; 6) motion in concentric circles; 7) spiral motion; 8) spatial motion;

- decentralized control: 1) swarm motion; 2) flocking motion; 3 ) collective motion.

The first four types of motion organization provide for synchronous or asynchronous motion of a group of $N$ AUVs along predetermined rectilinear trajectories. Moreover, the linear AUV speeds can be exactly the same $\left(v_{i}=v_{1}\right)$ or different $\left(v_{i} \neq v_{1}\right)$. In this paper, the ratio $\left(v_{i}=v_{1}\right)$ is adopted.

The next four types of motion organization provide for the AUVs motion along calculated curved trajectories, which imposes additional functions on their control systems for the current calculation of the motion parameters of the $i$-th AUV as a multi-agent search underwater system agent.

These first eight typical types of group motion are implemented using the centralized control principles, when the motion parameters are given to each AUV as a group element by the CCD (e.g. a group control post on the vessel). Such a device receives information about all the AUVs current state and the external environment. Consider the AUV group centralized motion organization features.

Line motion provides for AUV group straight line motion with equal intervals $h_{F}$ between them in the search mode [5]. The interval $h_{F}$ is selected taking into account the width $s$ of the search AUV equipment working zone, but not more than the AUV onboard communication systems range $r_{C}$ :

$$
h_{F}=\left\{\begin{array}{lll}
k_{1} s & \text { when } & r_{C} \geq s ; \\
r_{C} & \text { when } \quad r_{C}<s,
\end{array}\right.
$$

where $k_{1}<1$ is the "overlap" coefficient of the search AUV equipment working zone width $s$ when the neighboring underwater vehicles move in parallel tacks.

Upon detection of the underwater object (search target) by one of the AUVs, its coordinates, using the board communication systems, are transmitted to other AUVs; as a result, AUV group goes into the rebuild mode to radial converging motion in order to inspect the found object.

The echelon motion - each AUV moves in line behind the next by a certain distance $g$, is used during explosive objects search, when their operation can lead to the AUV's damage. If the radius of the object's striking effect is $p$, then the distance $h$ is also selected taking into account the AUV search equipment working zone width $s$, however, the AUV stepwise displacement $g$ is selected for safety reasons, but not more than the AUV on-board communication systems range $r_{C}$ :

$$
g=k_{2} \sqrt{p^{2}-s^{2} / 4} \text { when } g<r_{C},
$$




\section{АВТОМАТИЗАЦІЯ ТА КОМП'ЮТЕРНО-ІНТЕГРОВАНІ ТЕХНОЛОГІЇ №1〜2019}

where $k_{2}>1$ is the safety factor for the AUV safety distance.

Note that at $g \geq r_{C}$, a marine search operation, generally, is not carried out due to the AUV risk of loss.

Wedge motion is applied when search target - sunken object $(S O)$ - probable location, is known [16]. In this case, the group motion is constructed so that the wedge tip is directed to point $A(x ; y)$ with the target probable coordinates, and the AUV stepwise shift $g$ is selected based on AUV on-board communication systems range $r_{C}$ or the nearest AUV approach operational time $t_{0}$ to the found targets:

$$
g \leq \sqrt{r_{C}^{2}-h_{V}^{2}}
$$

or

$$
g \leq \sqrt{\left(v t_{0}\right)^{2}-h_{F}^{2}},
$$

where $v$ - is the AUV linear speed.

AUV group radial converging motion is used if one of the AUVs detects the desired object (DO), calculates its coordinates $A(x, y)$ and deciding on its comprehensive survey or accompaniment by the AUV group.

Generally, the AUV initial position can be arbitrary; however, their velocity vectors after the command for converging radial motion should be directed to point $A(x$, $y$ ). Moreover, the AUV ACS sub-task, which controls the approach safe distance to other group AUVs, is of particular relevance. The decision relevance of solving this sub-task is due to two main conditions:

- the appearance probability on the same radial line of two or more moving AUVs that previously moving in line;

- the inevitable convergence of several vehicles point $A(x, y)$ approach.

Both of these conditions require an operative change in AUV velocity $v$ and course $\varphi$ in order to avoid the collisions in the AUV group.

AUV group radial divergent motion is used:

- for a target search in the working circular zone with the AUV group carrier vessel location at its center;

- as transitional motion for organizing other types of motion.

In both cases, all the group AUVs simultaneously start the motion and the ACS of each of them solves the subtask $U_{R A}$ at the motion initial phase, when the group density is high and under these conditions each underwater vehicle falls on its given course $\varphi_{g}$. Subsequently, when the AUV group density decreased and the threat of collisions passed, each underwater vehicle ACS solves the subtask $U_{R C}$ to preserve the group entirety, that is, to prevent loss of communication $U_{R A}$ between them due to an increase in the distance $l$ between the neighboring AUVs. In this case, the radial diverging motion ceases with the condition $l<r_{C}$.
Group motion in a circle is proposed as an intermediate motion form at AUV group formation stage with its subsequent reorganization to fulfill a specific mission. The main objective of this motion is to maintain a given distance $h_{g}$ between the vehicles:

$$
h_{\min }<h_{g}<r_{C}
$$

where $h_{\min }-$ minimum safe distance between the neighboring AUVs.

Thus, in this mode, for each AUV, an intelligent ACS simultaneously solves two subtasks - the subtask $U_{R A}$ to prevent collisions from forward and backward by the operating vehicles, and the subtask $U_{R A}$ to maintain a reliable communication distance between the neighboring AUVs, that is, preserve the AUV group.

Motion along concentric trajectory-circles is proposed during the transition from the SO frontal search to the fan-like search (fig. 2). Usually the main task of the search is the simultaneous completion of the mission by all AUVs for the minimum possible time $T_{M}$.

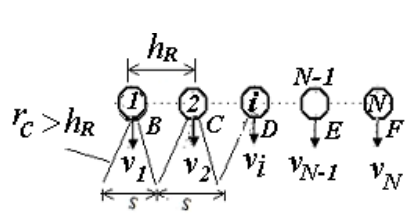

a)

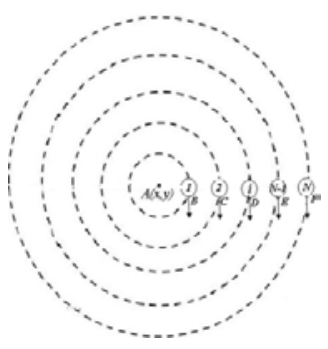

c)

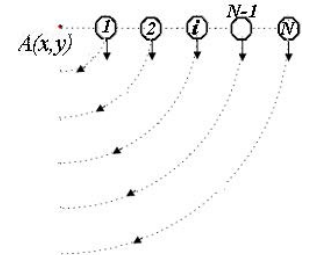

b)

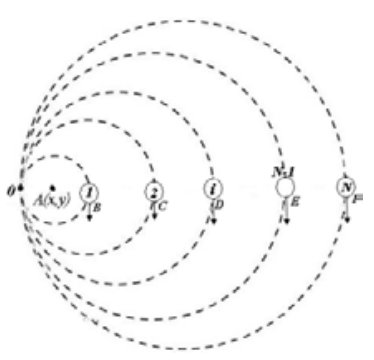

d)
Fig. 2. AUV group curved (along concentric trajectory-circles) motions

An AUV group is supposed for a search operation (for example, a SO search) in a certain underwater area. When AUVs are deployed from the carrier vessel, they are organized at the starting points in the working area $B$, $C, D, E$ and $F$ for the operation in such a way as to cover the largest possible area of the search water area, as in fig. 2 a. At the beginning of the mission, the group AUVs form concentric circles when conducting a search thus:

Group AUVs will begin the operation of forming concentric circles simultaneously with the virtual center $A(x, y)$, as shown in fig. $2 a$. Fig. $2 b$ shows the initial formations and movements of the AUVs with the indicated directions. AUVs move along the trajectory curve, form- 
ing predefined concentric circles that are formed in two ways, as in fig. $2 c$ and $d$.

1. In fig. $2 c$ all AUVs moving simultaneously in the same direction with a virtual center $A(x, y)$ for the formation of concentric circles. AUV 1 at point $B$, as a leader, forms a circle with virtual center $A(x, y)$. Other AUVs form concentric circles with the same virtual center $A(x, y)$.

2. In fig. $2 d$ AUV 1 forms a circular trajectory, and other AUVs form concentric circles through a common point 0 (circles common edge). In this case, the specific $i$-th AUV assigned to the $i$-th circle is set such a speed $v_{g i}$ that will ensure the simultaneous completion of the mission by each underwater vehicle to complete the search mission:

$$
v_{g i}=2 \pi r_{i} / T_{M} .
$$

Moreover, the distance $h_{R}$ between AUVs moving in neighboring circles should be no more than the on-board communication systems range $r_{C}$, of the vehicles, that is, $h_{R}<r_{C^{*}}$

Let the total number of homogeneous group AUVs be $N$, the AUV search equipment working zone width be $s$ and the maximum AUV speed equals to $v_{A U V}$.

Obviously, the working zone-circle radius $R$ and radius $r_{i}$ of the $i$-th circular path for the $i$-th AUV can be determined from the expressions, respectively:

$$
\begin{gathered}
R=k_{1} s N ; \\
r_{i}=\frac{s}{2}+k_{1}(i-1) s,
\end{gathered}
$$

where $i=1, \ldots N$.

Then, the search mission estimated time of the SO search along the concentric trajectories-circles is determined from the relation:

$$
T_{M}=R / v_{A U V} .
$$

In case of SO detection, the AUV group goes into radial converging motion mode for the SO comprehensive examination.

The AUV group motion along the Archimedes spiral (fig. 3) is used to examine the working area of a circular shape with an area $S_{U M}$ with maximum productivity under the conditions of limited number of AUVs in the group.

At the beginning of the mission, AUVs are deployed from the carrier vessel, and are located at the starting points $B, C, D, E, F$ and $G$ in the working area. During the mission, AUV 1 (leader) will move to point A (virtual center) along the BA trajectory. Other AUVs (as followers) move simultaneously along the following predefined trajectories during the search:

AUV 2 moves along path $C B$, AUV $i$ moves along $D C$ path, AUV N-2 moves along $E D$ path, AUV N-1 moves along $F E$ path, and AUV N moves along $G F$ path.
Apparently, AUV at point $G$ moves along the longest path. Consequently, the Archimedean spiral is formed by the AUV group as in fig. 3.

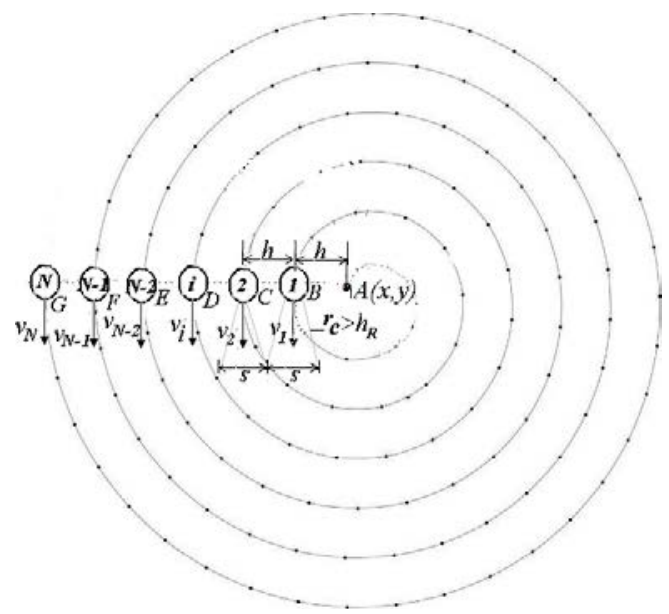

Fig. 3. AUV group curved (along the spiral of Archimedes) motions

If there are still tasks to be completed, group transition (GT) is carried out to the appropriate positions to perform the next tasks. The speed of each AUV is directly proportional to the path length, which makes the performance of the individual tasks simultaneously. After the tasks complete execution by the AUV group, they will make a GT together with equally defined distances from each other, and when they all come together with this configuration, they will begin to independently reorganize for a GT in order to start moving back to the collection source. Group motion control of this kind contains the following phases:

- the Archimedean spiral is built in polar coordinates $r=k_{1} s \phi$, where $r, \varphi-$ are, respectively, the current values of the radius vector and the polar angle of the spiral; the constructed spiral area $S_{A}$ should be equal to the working zone area $S_{U M}$ (circular search zone on the bottom surface), and the center of the spiral should be at point $A(x$, $y$ ) with the target probable coordinates:

$$
S_{A}=S_{U M}=\frac{1}{2} \int_{0}^{\phi M} r^{2} d \phi
$$

where $\varphi_{M}$ - Archimedean spiral polar angle with an area of $S_{U M}$; the Archimedes spiral number of turns $w_{U M}$ is calculated, with area $S_{A}=S_{U M}$ from the relation:

$$
w_{U M}=\frac{R_{U M}}{s}=\sqrt{\frac{S_{U M}}{\pi s^{2}}} ;
$$

- spiral length $L_{U M}$ is calculated from the expression

$$
L_{U M}=0,5 k_{1} S\left[\phi \sqrt{1+\phi^{2}}+\ln \left(\phi+\sqrt{1+\phi^{2}}\right)\right],
$$

where $\varphi=2 \pi w-$ polar angle of the calculated Archimedean spiral; 


\section{АВТОМАТИЗАЦІЯ ТА КОМП'ЮТЕРНО-ІНТЕГРОВАНІ ТЕХНОЛОГІЇ №1〜2019}

- the distance length $l_{A U V}$ that an individual AUV must move in the group, moving along its part of the spiral, is calculated:

$$
l_{A U V}=L_{U M} / N
$$

- mission execution time $T_{M}$ is calculated:

$$
T_{U M}=T_{i}=l_{A U V} / v
$$

where $v$ - is the AUV course speed;

- knowing the AUV distance length $l_{A U V}$ for the $i$-th group AUV, taking into account the dependence $r=s \varphi$ and using relation (1), we calculate the polar coordinates $\left\{r_{i}, \varphi_{i}\right\}$, which are the starting coordinates for the $i$-th group AUV;

- each AUV group is brought to its starting point on the spiral and each AUV motion control, as a group agent, is carried out along the allocated spiral portion for the inspection of the working zone as a whole, all AUVs completed operation simultaneously.

AUV group spatial control, in contrast to the plane control types considered above, is three-dimensional and, from the control point of view, is the most complex. Many options for such control organization are determined by many missions of water column research. Typical types of such motion include:

- control along triangular oblique ascending trajectories typical of underwater glider vehicles [15];

- circular spiral motion [17] and others.

Such types of group control are used when performing operational hydrophysical and hydrochemical water column researches in large water areas.

An analysis of the reduced main types of AUV group motion organization and the authors' own experience in the development and implementation of underwater robots motion ACS of makes it possible to formulate the following main tasks of their centralized control:

1) underwater mission planning task $Z_{P M}$ for an AUV group under the restrictions conditions on the number $N$ of AUVs in the group and for the underwater mission execution time $T_{U M}$. The result of solving this indicated task should be a generalized technological scheme of performing underwater operations, a proposal for the AUV group composition with specified technical characteristics, as well as reasonable requirements for the AUV control accuracy;

2) ACS synthesis task $Z_{G C}$ for AUV group motion selected for performing a given underwater mission, ensuring the AUVs coordinated motions along designated trajectories. The result of solving this task should be synthesized laws and control algorithms for the AUV group coordinated motion, ensuring maximum group productivity, the possibility of tasks operational redistribution between individual AUVs and high reliability of saving received information about the underwater situation in the area of offshore operations;
3) ACS synthesis task $Z_{A C}$ for a single AUV as a group agent, the result of which should be laws and algorithms for ACS of safe linear and trajectory motion of AUVs in the navigational proximity conditions of other group AUVs, marine environment unsteadiness, uncertainty of external disturbances and restrictions on energy and communication resources.

Thus, the current state of AUV group application problem, as the most productive form of conducting search operations and obtaining operational underwater information in large areas, requires a scientifically sound solution to the complex task $Z_{\text {MASz }}$ of their centralized group motion automation and contains three task groups:

$$
Z_{M A S Z}=\left\{Z_{P M} ; Z_{G C} ; Z_{A C}\right\}
$$

The main lines of research for solving these problems of AUV group motion automation with their centralized control are:

1) synthesis of reliable mathematical models of single AUV dynamics as a control object that operates in conditions of uncertainty;

2) development of mathematical modeling methods of AUV controlled group motion taking into account the underwater navigation environment conditions;

3) application of artificial intelligence elements (fuzzy, neural network and inverse technologies) in AUV motion control laws synthesis.

\section{DISCUSSION OF THE RECEIVED RESULTS}

The AUV group is a distributed structure of simple AUVs that use the self-organization principles. The article provides an overview of such tasks, illustrating the various algorithms used to solve problems associated with each task. Individual AUVs are mostly large, expensive, and require complex hardware. However, a group of small AUVs is cost-effective, operates more reliably than a single AUV, individual AUVs have lower equipment requirements, which reduces the maintenance costs, possesses fault tolerance, scalability and flexibility.

The article provides the AUV group control methods classification and gives the applications types necessary to ensure more efficient operations. For this, a classification of existing AUV group control methods is compiled and depending on the method of organizing the multiagent system, the methods are divided into - centralized and decentralized control. It is also necessary to distinguish auxiliary control - semi-decentralized.

The following types of centralized control: front (line) control; ledge (echelon) control; wedge control; radial control (converging and diverging); control in a circle; control on concentric circles; spiral control; spatial control; are considered. Analytical dependences for calculating the required time, quantities of AUVs and speed to be used are given. 


\section{CONCLUSIONS}

The classification, of existing AUV group control methods in the interests of studying and developing the World Ocean, which includes centralized and decentralized control, as well as a combination of these methods, is compiled.

A lot of applied scientific and technical tasks on the creation of centralized and decentralized control systems for a group of underwater vehicles performing a common mission and implementing flat rectilinear and curvilinear motion of underwater vehicles, as well as their group spatial motion, are formulated.

The obtained results can serve as a theoretical basis for the development of highly efficient systems for underwater vehicles group motion automation when performing operations in large water areas.

\section{REFERENCES}

[1] Zereika, Enrica, Bibuli, Marco, Miškovic', Nikola, Ridaoc, Pere, \& Pascoal, António (2018). Challenges and future trends in marine robotics. Vol. 46, 350-368. Retrieved from: https://doi.org/10.1016/j.arcontrol.2018.10.002.

[2] Slmnoiu, G. et al. (2017). Efficient Use of AUVs in the Maritime Environment. IOP Conf. Ser.: Mater. Sci. Eng. 209 012098, $1-11$.

[3] Kwiecień, Joanna (2018). A Swarm-Based Approach to Generate Challenging Mazes. Entropy, 1-18. Retrieved from: https://doi.org/10.3390/e20100762.

[4] Holembo, V., Bochkarov, O., \& Hrebenyak, A. (2009). Problema orhanizatsiyi uzhodzhenykh kolektyvnykh diy avtonomnykh mobilnykh pidvodnykh aparativ [The problem of organizing concerted collective action of autonomous mobile submarines]. Kompyuterni nauky ta informatsiyni tekhnolohiyi [Computer Science and Information Technology], 650, 167-173. Retrieved from: http://vlp.com.ua/files/special/23_0.pdf [in Ukrainian].

[5] Khasanovich, P. V., \& Medvedev, M. Yu. (2018). Gruppovoye upravleniye dvizheniyem mobil'nykh robotov v neopredelennoy srede s ispol'zovaniyem neustoychivykh rezhimov [Group control of the movement of mobile robots in an uncertain environment using unstable modes]. Robototekhnika, avtomatizatsiya $i$ sistemy upravleniya [Robotics, automation and control systems], 5 (60), 39-63. Retrieved from: https://doi.org/10.15622/sp.60.2 [in Russian].

[6] Holembo, V. A., \& Melnikov, R. H. (2017). Samoorhanizatsiya hrupy bezpilotnykh litalnykh aparativ [Self-organization of a group of unmanned aerial vehicles]. Vol. 8, 86-92 [in Ukrainian].

[7] Senanayake, M., \& Senthoorana, I. et. al. (2016). Search and tracking algorithms for swarms of robots: A survey. Robotics and Autonomous Systems, 75 (Part B), 422-434. DOI: 10.1016/j.robot.2015.08.010.

[8] Enayat, Maria, \& Khorasani, K. (2015). Semi-decentralized nonlinear cooperative control strategies for a network of heterogeneous autonomous underwater vehicles. International Journal of Robust and Nonlinear Control, 27 (16). DOI: 10.1002/rnc.3707.

[9] Yasuda, Gen'ichi (2015). Distributed Autonomous Control Architecture for Intelligent Mobile Robot Systems. Encyclopedia of Information Science and Technology. Third Edition, 10. DOI: 10.4018/978-1-4666-5888-2.ch650.

[10] Balasundaram, Madhevan, \& Sreekumar, M. (2017). Implementation of role assignment and fault tree analysis for multi robot interaction. International Journal of Robotics and Automation, Vol. 32, 214-223.

[11] Makarov, I. M. i drugiye. (2012). Smeshannyye strategii gruppovogo upravleniya v mnogoagentnykh robototekhnicheskikh sistemakh [Mixed group management strategies in multi-agent robotic systems]. Izvestiya YUFU. Tekhnicheskiye nauki [News SFU. Technical science], 8-13 [in Russian].

[12] Vodolazskiy, I. A., \& Yegorov (2019). Royevoy intellekt i yego naiboleye rasprostranonnyye metody realizatsii [Swarm intelligence and its most common implementation methods]. Molodoy uchonyy [Young Scientist], 4 (138), 147-153. Retrieved from: https://moluch.ru/archive/138/38900 [in Russian].

[13] Duarte, Miguel, Costa, Vasco, Gomes, Jorge, \& Rodrigues, Tiago et al. (2016). Evolution of Collective Behaviors for a Real Swarm of Aquatic Surface Robots. PLoS ONE, 1-25. Retrieved from: https://doi.org/10.1371/journal.pone.0151834.

[14] Wei, Dunwen, Wang, Feiran, \& Ma, Hongjiao (2019). Autonomous Path Planning of AUV in Large-Scale Complex Marine Environment Based on Swarm Hyper-Heuristic Algorithm. Appl. Sci., 9 (13), 22.

[15] Blintsov, V. S., Aloba, L. T., \& Tkhy, D. F. (2016). Sovremennyye zadachi gruppovogo upravleniya dvizheniyem avtonomnykh neobitayemykh podvodnykh apparatov [Modern tasks of group control of the movement of autonomous uninhabited underwater vehicles]. Zbirnik naukovikh prats' NUK [Collection of scientific works of NUS]. Mykolayiv: NUS, 3 (465), 91-99. Retrieved from: http://znp.nuos.mk.ua/archives/2016/3/15.pdf [in Russian].

[16] Vel'tishchev, V. V., Yegorov, S. A., \& Kropotov, A. N. i dr. (2014). Osobennosti razrabotki navigatsionnogo obespecheniya gruppirovki avtonomnykh apparatov [Features of the development of navigation support grouping of autonomous devices]. Fundamental'naya i prikladnaya gidrofizika [Fundamental hydrophysics], 7 (2), 41-45 [in Russian].

[17] Blíntsov, S. V. (2014). Teoretychni osnovy avtomatychnoho keruvannya avtonomnymy pidvodnymy aparatamy [Theoretical basics of automatic control of autonomous submarines]. Mykolayiv: Vid-vo NUK [NUS Publishing House] [in Ukrainian].

\section{BIBLIOGRAPHY}

[1] Zereika, Enrica, Bibuli, Marco, Miškovic', Nikola, Ridaoc, Pere, \& Pascoal, António (2018). Challenges and future trends in marine robotics. Vol. 46, 350-368. URL: https://doi.org/10.1016/j.arcontrol.2018.10.002.

[2] Slmnoiu, G. et al. (2017). Efficient Use of AUVs in the Maritime Environment. IOP Conf. Ser.: Mater. Sci. Eng. 209012098 , 1-11. 


\section{АВТОМАТИЗАЦІЯ ТА КОМП'ЮТЕРНО-ІНТЕГРОВАНІ ТЕХНОЛОГІЇ № 1 - 2019}

[3] Kwiecień, Joanna (2018). A Swarm-Based Approach to Generate Challenging Mazes. Entropy, 1-18. URL: https://doi. org/10.3390/e20100762.

[4] Голембо, В., Бочкарьов, О., \& Гребеняк, А. (2009). Проблема організації узгоджених колективних дій автономних мобільних підводних апаратів. Комп 'ютерні науки та інформачійні технології, 650, 167-173.

[5] Хасанович, П. В., \& Медведев, М. Ю. (2018). Групповое управление движением мобильных роботов в неопределённой среде с использованием неустойчивых режимов. Робототехника, автоматизащия и системы управления, 5 (60), 39-63. URL: https://doi.org/10.15622/sp.60.2.

[6] Голембо, В. А., \& Мельніков, Р. Г. (2017). Самоорганізація групи безпілотних літальних апаратів. Т. 8, 86-92.

[7] Senanayake, M., \& Senthoorana, I. et.al. (2016). Search and tracking algorithms for swarms of robots: A survey. Robotics and Autonomous Systems, 75 (Part B), 422-434. DOI: 10.1016/j.robot.2015.08.010.

[8] Enayat, Maria, \& Khorasani, K. (2015). Semi-decentralized nonlinear cooperative control strategies for a network of heterogeneous autonomous underwater vehicles. International Journal of Robust and Nonlinear Control, 27 (16). DOI: 10.1002/rnc.3707.

[9] Yasuda, Gen'ichi (2015). Distributed Autonomous Control Architecture for Intelligent Mobile Robot Systems. Encyclopedia of Information Science and Technology. Third Edition, 10. DOI: 10.4018/978-1-4666-5888-2.ch650.

[10] Balasundaram, Madhevan, \& Sreekumar, M. (2017). Implementation of role assignment and fault tree analysis for multi robot interaction. International Journal of Robotics and Automation, Vol. 32, 214-223.

[11] Макаров, И. М. и др. (2012). Смешанные стратегии группового управления в многоагентных робототехнических системах. Известия ЮФУ. Технические науки, 8-13.

[12] Водолазский, И. А., \& Егоров (2019). Роевой интеллект и его наиболее распространённые методы реализации. Молодой учёный, 4 (138), 147-153. URL: https://moluch.ru/archive/138/38900.

[13] Duarte, Miguel, Costa, Vasco, Gomes, Jorge, \& Rodrigues, Tiago et al. (2016). Evolution of Collective Behaviors for a Real Swarm of Aquatic Surface Robots. PLoS ONE, 1-25. URL: https://doi.org/10.1371/journal.pone.0151834.

[14] Wei, Dunwen, Wang, Feiran, \& Ma, Hongjiao (2019). Autonomous Path Planning of AUV in Large-Scale Complex Marine Environment Based on Swarm Hyper-Heuristic Algorithm. Appl. Sci., 9 (13), 22.

[15] Блинцов, В. С., Алоба, Л. Т., \& Тхы, Д. Ф. (2016). Современные задачи группового управления движением автономных необитаемых подводных аппаратов. Збірник наукових пращь НУК. Миколаїв : НУК, 3 (465), 91-99. URL: http://znp.nuos.mk.ua/archives/2016/3/15.pdf.

[16] Вельтищев, В. В., Егоров, С. А., \& Кропотов, А. Н. и др. (2014). Особенности разработки навигационного обеспечения группировки автономных аппаратов. Фундаментальная гидрофизика, 7 (2), 41-45.

[17] Блінцов, С. В. (2014). Теоретичні основи автоматичного керування автономними підводними апаратами. Миколаїв : Вид-во НУК. 